\title{
Effect of Mulches on Growth and Yield of Chickpea (Cicer arietinum L.)
}

\author{
Daleshwar Rajak $^{1 *}$ and Pradeep Prasad ${ }^{2}$ \\ ${ }^{1}$ Agricultural Engineering, ${ }^{2}$ Agronomy, Zonal Research Station, Darisai (BAU), East \\ Singhbhum, Jharkhand, India \\ *Corresponding author
}

\begin{tabular}{|c|c|}
\hline & A B S T R A C T \\
\hline Keywords & \multirow{4}{*}{$\begin{array}{l}\text { A field experiment was conducted during winter season of } 2005-06 \text { to } 2007-08 \text { at } \\
\text { ZRS, Darisai, East Singhbhum, Jharkhand to study the comparative performance } \\
\text { of mulching material in chick pea. Maximum grain yield }(10.14 \mathrm{q} / \mathrm{ha}) \text { was recorded } \\
\text { in treatment having mulch with karanj leaf followed by combination of karanj leaf } \\
\text { and dust }(8.56 \mathrm{q} / \mathrm{ha}) \text { and both these treatments were significantly better than the } \\
\text { others. Soil moisture content }(15.40 \%) \text { in } 20-30 \mathrm{~cm} \text { depth at the time of harvest } \\
\text { was highest in the treatment of karanj field and minimum }(11.77 \%) \text { in the } \\
\text { treatment without mulch. The highest net income (Rs } 13270.00) \text { and benefit cost } \\
\text { ratio (1.89) was obtained for mulching with karanj leaf. }\end{array}$} \\
\hline $\begin{array}{l}\text { Chick pea, } \\
\text { Mulches, } \\
\text { Moisture content, } \\
\text { Benefit cost ratio. }\end{array}$ & \\
\hline Article Info & \\
\hline $\begin{array}{l}\text { Accepted: } \\
\text { 29 June } 2017 \\
\text { Available Online: } \\
\text { 10 July } 2017\end{array}$ & \\
\hline
\end{tabular}

\section{Introduction}

Chickpea (Cicer arietinum L.) is world's second most cultivated grain legume grown over 10.2 million hectare. Chickpea is grown as a winter crop in the Indian subcontinent, which accounts for nearly $85 \%$ of the chickpea area sown worldwide. It is also an important crop in West Asia and Mediterranean region. Seed is the main edible part of the plant and is a rich source of protein, carbohydrates and minerals. In India chickpea is generally grown using stored soil moisture after rainy season. Moisture stress is the most prevalent environmental factor limiting plant growth, survival and productivity in chickpea (Bohnert and Jenson, 1995). Moisture deficit affects seed germination and seedling establishment in the field, however, mulching vary in their capacity to tolerate moisture stress. Chickpea is believed to be tolerant to drought condition, but there is little published evidence to support this contention (Saxena, 1984). Relative water content (RWC) is one of the important parameter to measure water status of the tissue (Barrs and Weatherley, 1962). Gradual decrease in RWC with increase in stress and greater reduction afterwards under severe stress has been reported in chickpea (Deshmukh et al., 2000). High RWC under moisture stress denotes ability of plants to tolerate moisture stress (Uprety and Sirohi, 1987). The beneficial effect of mulches on plants includes earlier production (Call and Courter, 1989; Decoteau et al., 1989) greater total yield (Jensen, 1990) and reduced insect and disease problems 
(Greenough et al., 1990) Use of different types of mulches such as plastic mulch, paddy straw, karanj leaf, dust and crop residues have been found to conserve moisture, control weeds, moderate soil temperature and increase in yield of different crops, however very little work seems to have been undertaken on the chickpea under organic mulch and with combination of mulch conditions for sub- humid tropical climate of East Singhbhum, Jharkhand, India. The present experiment is undertaken to study the influence of various mulches and combination of mulch on growth, yield and to evaluate the economics of the rainfed chick pea crop.

\section{Materials and Methods}

The field experiment was conducted at Zonal Research Station, Darisai, East Singhbhum, Jharkhand during winter season of 2005-06 to 2007-08. The field is located at $23^{\circ} 36^{\prime}$ North latitude, $86^{\circ} 54^{\prime}$ East longitude with an altitude of $124 \mathrm{~m}$ above mean sea level. The mean annual rainfall is $1200 \mathrm{~mm}$ and mean temperature is $28^{\circ} \mathrm{C}$. The soil of the experimental field was sandy loam in texture having soil $\mathrm{pH} 5.58$, organic carbon $0.48 \%$, field capacity $17.65 \%$, permanent wilting point $7.8 \%$ and bulk density $1.58 \mathrm{gm} / \mathrm{cm}^{3}$ respectively. The available nitrogen, phosphorous and potassium were 118.8, 63.55 and $136.0 \mathrm{~kg}$ per hectare, respectively. The following six mulching treatments were applied in a randomized black design with 4 replication: $\mathrm{T}_{1}$ - Kranj leaf, $\mathrm{T}_{2}$ - Paddy straw, $\mathrm{T}_{3}$-dust, $\mathrm{T}_{4^{-}}$combination of $\mathrm{T}_{1}+\mathrm{T}_{3}, \mathrm{~T}_{5}$ combination of $\mathrm{T}_{2}+\mathrm{T}_{3}, \mathrm{~T}_{6}$-Control,

Sowing of seeds of chickpea var. PantG-114 was undertaken in the field at crop spacing of $30 \mathrm{~cm} \times 10 \mathrm{~cm}$. on $25^{\text {th }}$ November 2005 during first year. $29^{\text {th }}$ November 2006 during second year and $27^{\text {th }}$ December 2007 during third year, the fertilizer dose of $\mathrm{N}, \mathrm{P}_{2} \mathrm{O}_{5}$ and $\mathrm{K}_{2} \mathrm{O}$ was applied at rate of 20: 40:20 $\mathrm{kgha}^{-1}$. Observation on plant height, No. of branches/plant, No of pod/plant and grain yield were recorded. The income from produce for different treatments was calculated taking into account the wholesale prices of chickpea. To study the soil moisture content under the different treatments, profile soil sample were drawn using screw auger from all the mulching treatments at vertical depth of $0-10 \mathrm{~cm}, 10-20 \mathrm{~cm}$ and $20-30 \mathrm{~cm}$ at the time of sowing, 30 days after sowing and at the time of harvest. The moisture content was determined through gravimetric method.

The cost of cultivation was worked out for each treatment. The cost of cultivation includes expenses incurred in land preparation, interculture operation, fertilizer, crop protection measures and harvesting with labour charges. The net return was evaluated by subtracting the cost of cultivation from the income obtained through produce for each treatment. The benefit cost ratio $(\mathrm{B}: \mathrm{C})$ was estimated dividing income obtained from produce by total cost of production for each treatment. The data collected from the experiment was analysed statistically using the analysis of variance procedure, appropriate for the randomized block design. The test of significance was carried out at 5 per cent level.

\section{Results and Discussion}

\section{Effect of mulches on biometric parameters}

Mulches significantly influenced the growth characters such as plant height and number of branches in chickpea. The biometric observations are given in table 1 . The maximum plant hight of $47.76 \mathrm{~cm}$ and number of branches plant ${ }^{-1}$ of 3.85 was observed in karanj leaf whereas the least plant height $36.25 \mathrm{~cm}$ and less number of branches plant $^{-1}$ (2.80) was recorded in control. The improved growth characters in karanj leaf might be due to optimum availability of nutrients and moisture. 
Table.1 Effect of mulching on plant height, number of branches/plant, number of pod/plant, grain yield and B: C ratio of Chickpea (Pooled data of three year)

\begin{tabular}{|l|c|c|c|c|c|c|}
\hline \multicolumn{1}{|c|}{ Treatment } & $\begin{array}{c}\text { Plant } \\
\text { height } \\
\text { (cm) }\end{array}$ & $\begin{array}{c}\text { No of } \\
\text { branches/ } \\
\text { plant }\end{array}$ & $\begin{array}{c}\text { No of } \\
\text { pod/plant }\end{array}$ & $\begin{array}{c}\text { Grain } \\
\text { yield } \\
\text { (q/ha) }\end{array}$ & $\begin{array}{c}\text { Net } \\
\text { income } \\
\text { (Rs) }\end{array}$ & $\begin{array}{c}\text { B: C } \\
\text { Ratio }\end{array}$ \\
\hline $\mathbf{T}_{\mathbf{1}}$-Kranj leaf & 47.76 & 3.85 & 48.60 & 10.14 & 13270.00 & 1.89 \\
\hline $\mathbf{T}_{\mathbf{2}}$-Straw & 44.76 & 3.40 & 38.50 & 7.35 & 7770.00 & 1.12 \\
\hline $\mathbf{T}_{\mathbf{3}}$ - Dust & 40.10 & 3.13 & 33.60 & 6.25 & 5560.00 & 0.80 \\
\hline $\mathbf{T}_{\mathbf{4}}$ - combination of T1+T3 & 46.35 & 3.55 & 45.85 & 8.56 & 10120.00 & 1.45 \\
\hline $\mathbf{T}_{\mathbf{5}}$ combination of T2+T3 & 41.96 & 3.30 & 35.20 & 7.88 & 8900.00 & 1.30 \\
\hline $\mathbf{T}_{\mathbf{6}}$ - Control (No mulch) & 36.25 & 2.80 & 30.65 & 4.74 & 2580.00 & 0.37 \\
\hline CD (5\%) & 5.96 & 0.23 & 6.31 & 2.65 & - & - \\
\hline CV $\mathbf{( \% )}$ & 9.69 & 0.39 & 10.81 & 23.01 & - & - \\
\hline
\end{tabular}

Table.2 Moisture content (\%) due to different mulching materials (Pooled data of three year)

\begin{tabular}{|c|c|c|c|c|}
\hline \multirow[t]{2}{*}{ Treatment } & \multirow[t]{2}{*}{$\begin{array}{l}\text { Depth } \\
\text { (cm) }\end{array}$} & $\begin{array}{l}\text { Soil moisture } \\
\text { content }(\%) \text { at the } \\
\text { time sowing }\end{array}$ & $\begin{array}{l}\text { Soil moisture } \\
\text { content }(\%) \text { at } \\
\text { 30 DAS }\end{array}$ & $\begin{array}{l}\text { Soil moisture content } \\
(\%) \text { at the time of } \\
\text { harvest }\end{array}$ \\
\hline & & Mean & Mean & Mean \\
\hline \multirow{3}{*}{$T_{1}$-Kranj leaf } & $0-10$ & 11.27 & 11.65 & 8.69 \\
\hline & $10-20$ & 13.75 & 13.49 & 11.99 \\
\hline & $20-30$ & 17.26 & 16.39 & 15.40 \\
\hline \multirow{3}{*}{$\mathbf{T}_{2^{-}}$Straw } & $0-10$ & 11.27 & 10.71 & 6.99 \\
\hline & $10-20$ & 13.75 & 12.13 & 10.26 \\
\hline & $20-30$ & 17.26 & 15.63 & 14.64 \\
\hline \multirow[t]{3}{*}{$T_{3^{-}}$Dust } & $0-10$ & 11.27 & 9.36 & 7.31 \\
\hline & $10-20$ & 13.75 & 11.48 & 10.54 \\
\hline & $20-30$ & 17.26 & 14.51 & 13.99 \\
\hline \multirow[t]{3}{*}{$T_{4}$ - combination of $T_{1}+T_{3}$} & $0-10$ & 11.27 & 11.13 & 7.23 \\
\hline & $10-20$ & 13.75 & 12.90 & 11.37 \\
\hline & $20-30$ & 17.26 & 15.81 & 14.85 \\
\hline \multirow[t]{3}{*}{$T_{5}$-combination of $T_{2}+T_{3}$} & $0-10$ & 11.27 & 9.30 & 6.71 \\
\hline & $10-20$ & 13.75 & 11.70 & 10.84 \\
\hline & $20-30$ & 17.26 & 15.19 & 14.29 \\
\hline \multirow[t]{3}{*}{$\mathbf{T}_{6-}-$ Control } & $0-10$ & 11.27 & 5.66 & 5.12 \\
\hline & $10-20$ & 13.75 & 10.89 & 9.54 \\
\hline & $20-30$ & 17.26 & 14.63 & 11.77 \\
\hline
\end{tabular}

Effect of mulches on the yield and yield attributes

Mulches significantly affected the number of pods per plant and grain yield. Significantly maximum number of pods per plant (48.60) was recorded with karanj leaf. The karanj leaf recorded maximum grain yield (10.14 $\left.\mathrm{qha}^{-1}\right)$ and was statistically similar with combination of karanj leaf and dust (8.56 $\left.\mathrm{qha}^{-1}\right)$. The minimum (4.74 $\mathrm{qha}^{-1}$ ) was recorded with control (No mulch) (Table 1). Higher yield under mulch treatments might be due to its favorable effect on weed control. The higher 
fruit yield under mulch may also be ascribed to reduced nutrient losses due to weed control and improved hydrothermal regimes of soil (Ashworth and Harrison, 1983, Bhella, 1988 and Singh, 2005). Similar beneficial effect of organic mulches on yield was also reported by earlier investigator (Asiegha, 1991, Srivastava et al., 1994).

\section{Soil moisture content}

Soil moisture content (\%) increased as the depth increases. Similar finding was also reported by Shirahatti et al., (2007). The highest moisture content was recorded with Kranj leaf and lowest with control (No mulch) (Table 2). This might be due to less evaporation from the soil surface.

\section{Cost economics}

It is observed from the table 1 that the highest net income was realized in karanj leaf (Rs 13270.00) compared to other treatments whereas the lowest was recorded in control (Rs 2580.00). The benefit-cost ratio (BCR) was worked out for all the treatments using net income generated and cost of cultivation of chick pea. The maximum BCR was noted in karanj leaf (1.89). The lowest BCR of 0.37 was recorded in control (No mulch). Thus it may be concluded that in chickpea, higher yields (10.14 qha $\left.^{-1}\right)$ was recorded in karanj leaf mulch with maximum plant height and number of branches plant ${ }^{-1}$. The maximum BCR was noted in karanj leaf (1.89). It was also observed that soil moisture increased along the vertical direction as the depth increases and was found higher in karanj leaf. Hence for chick pea karanj leaf mulch is recommended for getting higher yield.

\section{References}

Ashworth, S. and Harrison, H. 1983. Evolution of mulches for use in thehome garden. J. Horticultural Sci.,
18(2): 180-182.

Asiegha, J.E. 1991. Response of tomato and egg plant to mulching and nitrogen fertilization under tropical conditions. $J$. Horticultural Sci., 46: 33-41.

Barrs, H.D. and Weatherly. 1962. A reexamination of the relative turgidity technique for estimating water deficit in leaves. Australian J. Biol. Sci., 15: 413428.

Bhella, H.S. 1988. Tomato response of trickle irrigation and black polyethylene mulch. J. American Society of Horticultural Sci., 113(4): 543-546.

Bohnert H.J, and Jensen, R.G. 1995. Strategies for engineering water stress tolerance in plants. Trends in Biotechnol., 14: 89-97.

Call, R.E. and Courter, J.W. 1989. Response of bell pepper to raised beds, black plastic mulch spunbonded row cover and trickle irrigation. In: Proceeding of the $21^{\text {st }}$ NAPC. Pp. 140-146.

Decoteau, D.R., Kasperbauer, M.J. and Hunt, P.G. 1989. Mulch surface color effects yield of fresh market tomatoes. $J$. American Society of Horticulture Sci., 114: 216-220.

Deshmukh P.S., Sairam, R.K, Kumari, S., Kushwaha, S.R. and Kumar, P. 2000. Physiological traits for yield improvement of chickpea in drought prone environments. Proceedings of the National Seminar on Plant Physiology at Interface of Agri-horticulture and Industry held during $20^{\text {th }}$ December 1999-1 st January 2000 at RAU, Udaipur, India, pp. 104.

Greenough, D.R., Black, L.L., Bond, W.P. 1990. Aluminium surfaced mulch: an approach to control of tomato spotted wilt virus in solanaceous crops. Plant Dis. 74: 805-808.

Jensen, M.H. 1990. Protected Cultivation-a globle review of plastics in agriculture. In: Proceedings of the $11^{\text {th }}$ International 
Congress on the Use of Plastics in agriculture.26 February -2 March, New Delhi, India, pp. E3-E10.

Saxena, N.P.1984. The Chickpeas, pp 419452.

Singh, R. 2005. Influence of mulching on growth and yield of tomato (Lycopersicon esculentum) in north India plains. J. Vegetable Sci., 32(1): 55-58.

Shirahatti, M.S., Itnal, C.J. and Gouda, D.S.M. 2007. Impact of differential methods of irrigation on yield levels of cotton in red soils. Karnataka J. Agri. Sci., 20(1): 96-98.

Srivastava, P.K., Prakash, M.M., Sawani, N.G., Raman, S. 1994. Effect of drip irrigation and mulching on tomato yield. Agri. Water Management, 25: 179-184.

Uprety D.C. and Sirohi, G.S. 1987. Comparative study on the effect of water stress on photosynthesis and water relations of triticale, ray and wheat. J. Agron. Crop Sci., 159: 349355.

\section{How to cite this article:}

Daleshwar Rajak and Pradeep Prasad. 2017. Effect of Mulches on Growth and Yield of Chickpea (Cicer arietinum L.). Int.J.Curr.Microbiol.App.Sci. 6(7): 3893-3897. doi: https://doi.org/10.20546/ijcmas.2017.607.401 